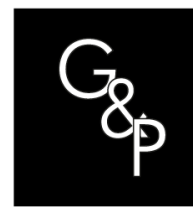

\title{
A bibliometric study on the use of games in the Production Engineering area
}

\author{
Um estudo bibliométrico sobre o uso de jogos na área de Engenharia \\ de Produção
}

\author{
Carlos Antonio Gonçalves Rosado 10 , Marcio Coutinho de Souza² \\ ${ }^{1}$ Instituto Federal de Minas Gerais - IFMG, Campus Governador Valadares, Governador Valadares, MG, Brasil. \\ E-mail: carlos.rosado@ifmg.edu.br \\ 2Universidade Federal dos Vales do Jequitinhonha e Mucuri - UFVJM, Teófilo Otoni, MG, Brasil. \\ E-mail: marcio.souza@ufvjm.edu.br
}

How to cite: Rosado, C. A. G., \& Souza, M. C. (2021). A bibliometric study on the use of games in the Production Engineering area. Gestão \& Produção, 28(3), e5171. https://doi.org/10.1590/1806-96492021v28e5171

\begin{abstract}
Keeping the student focused for long periods of time has been a challenge for teachers. The adoption of new teaching strategies in which students leave the position of listeners and share with the master the active position is already known and even adopted. These strategies give students the opportunity to have more interactive experiences, stimulate independent thinking, create discussions within the group thus contribute to the improvement of the teaching- learning process. In that sense, the use of educational games has been an alternative, as they can mitigate the difficulty that students have in making the parallel between the concepts theorists learned from situations of application of this knowledge. Monitor the growth of the literature and research patterns in a given thematic area is an important step to understand the development of this domain. Therefore, the bibliometrics has been an emerging area, as it aims to describe, evaluate and monitor research published in a given field of knowledge. In this way, it is defined as the general objective of this work to map and characterize publications on the use of games and related terms in Production Engineering from bibliometric research in the annals of the National Meeting of Production Engineering. In this research, techniques such as Citation, Bibliographic Coupling, Co-author, Cocitation and Co- word were used, from which bibliometric maps are generated with the aid of the VOSviewer software, in which, for example, the most used keywords are shown; institutions and authors who publish works in the field; the authors who are engaged bibliographically; those who work together; and those that appear simultaneously in the reference lists.
\end{abstract}

Keywords: Games; Bibliometric; Teaching-learning; Production engineering; Vosviewer; Engineering education.

Resumo: Manter o aluno concentrado durante longos períodos de exposição tem sido um desafio para os docentes. A adoção de novas estratégias de ensino em que os alunos deixam a posição de ouvintes e dividem com o mestre a posição ativa já é conhecida e até mesmo adotada. Essas estratégias dão aos discentes a oportunidade de viverem experiências mais interativas, estimulam o pensamento independente, criam discussões dentro do grupo e contribuem, assim, para a melhoria do processo ensino-aprendizagem. Nesse sentido, a utilização de jogos educacionais tem sido uma alternativa, pois estes podem atenuar a dificuldade que os alunos têm em fazer o paralelo entre os conceitos teóricos aprendidos com situações de aplicação desses conhecimentos.

Received May 1, 2019 - Accepted Dec. 22, 2019

Financial support: None.

This is an Open Access article distributed under the terms of the Creative Commons Attribution License, which permits

unrestricted use, distribution, and reproduction in any medium, provided the original work is properly cited. 
Monitorar o crescimento da literatura e os padrões de pesquisa em determinada área temática é um passo importante para entender o desenvolvimento desse domínio. Assim, a bibliometria tem sido uma área emergente, pois visa descrever, avaliar e monitorar as pesquisas publicadas em determinado campo do conhecimento. Dessa forma, fica definido como objetivo geral deste trabalho mapear e caracterizar as publicações sobre o uso de jogos e termos correlatos na Engenharia de Produção a partir de pesquisa bibliométrica nos anais do Encontro Nacional de Engenharia de Produção. Nesta pesquisa são utilizadas as técnicas Citation, Bibliographic Coupling, Co-author, Co-citation e Co-word, a partir das quais são gerados mapas bibliométricos com o auxílio do software VOSviewer, em que são mostrados, por exemplo, as palavras-chave mais utilizadas; instituições e autores que publicam trabalhos na área; os autores que estão acoplados bibliograficamente; aqueles que trabalham em conjunto; e os que aparecem simultaneamente nas listas de referências.

Palavras-chave: Jogos; Bibliometria; Ensino-aprendizagem; Engenharia de produção; Vosviewer; Ensino em engenharia.

\section{Introduction}

Changes in society over the years have notoriously reflected within the environment of organizations, making them increasingly complex and dynamic. To survive and remain profitable, companies must adapt to the changes imposed by the progressively globalized world. Technological changes have been a tool used by companies to survive this increasingly competitive market (Biasca, 2005).

Companies, mainly due to the dynamism and velocity of changes, have a decreasingly time to develop or train a professional capable of meeting their demands. In this way, companies no longer seek professionals for training, but those who are ready to face the diversity within organizations and who, moreover, are able to keep up with the constant market and technological developments in which they are inserted.

In this context, knowledge ends up becoming the main driver for survival as well as growth of companies and individuals looking for permanence or placement in the job market. Teaching institutions are, therefore, an important mechanism for the dissemination of knowledge, being a bridge between the student and the company.

In this scenario, a course that has stood out is Production Engineering. The institutions that offer this course have the challenge of training students capable of designing, modeling, implanting, putting into operation and improving production systems, in addition to several other attributions given to professionals in this area. They use specialized knowledge of mathematics, physics, humanities and social sciences, that is, they are a multidisciplinary professional capable of solving problems and keeping companies running, providing technical support to improve the financial results of organizations (ABEPRO, 2001).

Since knowledge dissemination is one of the functions of research institutions teaching, it is up to your teachers to understand the needs of students and the job market work to thus reconcile interests. Interface knowledge theory and practice required by companies has been a challenge for teachers who deal with the most diverse areas of knowledge and, according to the scope of the work, with disciplines focused on the Production Engineering course. Credit institutions teaching materials have intellectual material, but far from the practical experience that organizations want. In this context, students find it difficult to make a parallel between a concept presented by the teacher and a practical application in which the companies may demand of this new professional, since many professors never experienced the routine of a company. 
New teaching strategies in which students leave the position as listeners and share the active position with the master, are already accepted and used in several educational institutions. Giving students the opportunity to live more interactive experiences, which stimulates independent thinking, creating discussions within the group, contributes to the improvement of the teaching-learning process. Educational games in this sense are a great ally in this task. Games are well accepted by new generations of young people, but use in higher education is still early (Alves et al., 2017; Costa \& Silva, 2017; Odenweller et al., 1998; Teixeira \& Teixeira, 1998).

Associating theoretical concepts and practical application and at the same time improving the teaching-learning process can be easily achieved with the use of games that simulate a corporate environment, where those involved try to solve problems quite close to those that happen in the business environment and consequently in real life and that are especially far from the theoretical reality presented by the school. The practice of executing tasks, naturally present in games, ends up being an excellent way to improve learning (Gramigna, 2007a; Pantaleão et al., 2003).

So, from a bibliometric analysis, how is the scientific production about the use of games applied to Production Engineering characterized in the annals of the National Meeting of Production Engineering (ENEGEP)?

In this way, we seek to map publications on the use of games and related terms in Production Engineering mainly from the perspective of the areas of Production Management and Quality Management from a bibliometric research in the annals of ENEGEP of the last 10 years.

\section{Theoretical review}

\subsection{Games as a strategy for improving the teaching-learning process}

According to Silva \& Amaral (2011), each student has a particular way of learning. Teachers in the face of numerous factors in the educational environment, do not have enough time for individualized guidance for the student, so it becomes necessary to use different educational strategies so that each one can learn independently, breaking the barriers of difficulty.

Among these strategies is the pedagogical game, which aims to assist in the construction of knowledge and can be used as an alternative to improve student performance in some content that is difficult to learn, moreover to encouraging attitudes of participation, cooperation and initiative. These attitudes compel students to make decisions, providing psychic development and the mandatory revision of some school concepts so that they can effectively solve a problem situation. (Silva \& Amaral, 2011, p. 2).

Theoretical concepts, when associated with a practical application, improve the teaching-learning process. The use of games that simulate a real life context ends up being a good strategy for the practical application of the theoretical knowledge obtained previously (Pantaleão et al., 2003).

The game is one of the most important instruments in education in general. Through it, people exercise skills fundamental for their integral development, including self- discipline, sociability, affectivity, moral values, team spirit and common sense. (Gramigna, 2007a, p. 2). 
According to Schafranski \& Tubino (2013, p. 3), games can be seen as: "spontaneous activity carried out by one or more people, governed by rules that determine who will win, existing within time and space limits".

In this sense, completes Gramigna (2007a), the games, since always, cause great fascination to the players. Whether due to the competitive aspect, interaction or mere time spent, given that before the definition of the activity and following the predefined rules, at the end a winner was reached, indicating the one with the greatest set of skills, whether physical and/or intellectual.

The student through experimentation, freed from the fear of making mistakes, builds an environment conducive to learning. Testing each alternative and verifying the consequences ends up bringing benefits to the process, since the error happens in a simulated situation and not in the real world present in the business and/or factory environment. The fear of making mistakes ends up being minimized in games. As a parallel, there are medical procedures performed by medical students on dolls that simulate human behavior. This is the time for trial and error. The doll does not lose its life, that is, there is no real consequence (Crookall, 2010).

Experiencing a situation close to the real one allied with the act of performing an activity ends up being an excellent way to improve learning. As the game occurs, the student is not just hearing or seeing something, he is in an active position to carry out the activity. Confucius, a Chinese thinker and philosopher, said: "What I hear, I forget. What I see, I remember. What I do, I understand ", or in the words of Gramigna (2007a, p. 14): "I hear and remember; I read and memorize; I do and learn".

For Prensky (2001) there is a revolution in the way of learning and teaching. We are breaking the chains of pain and suffering of the traditional teaching-learning process and we are moving towards a learning process where fun and satisfaction will be present in students, parents, teachers, trainers, instructors, supervisors and other people involved in the process.

The games date back thousands of years (Gramigna, 2007a). These, along with simulations, puzzles, plays, case studies and other related activities have been used successfully in countless training and education situations for many centuries. Games have been part of the growth and adaptation of human beings since the school period. However, defining what the game represents in people's lives is not a simple task (Kroehnert, 2001), so this research did not focus on this aspect.

\subsubsection{Business games}

For Sauaia (1995) business games are a learning methodology to which participants play managerial roles in fictional companies. These would be a derivation of the war games that arose in China around $3000 \mathrm{BC}$. for education and skill development with war simulation known as Wei-Hai.

Santos (2003) indicates that the first corporate games emerged as an adaptation and evolution of war games, in 1956, in the United States, from the game Top Management Decision Game, developed by the American Management Association.

Still in the 1950s, after success in terms of the results achieved, countries like Germany and England also adopted it as a way of training executives (Gramigna, 2007b). Martinelli (1988) adds that, from 1963, computers were inserted into games, which developed them substantially. Teachers started using this technique, so that students could simulate the activities of a large company with a high level of precision. From then on, a large number of companies started to use business games as a training tool for their executives. 
The advent of computers, the migration of large computers to microcomputers and their popularization boosted business games, as they allowed us to work with more complex models, in a more agile way, with faster data processing and with greater ease of use, making games more dynamic (Santos, 2003; Sauaia, 1995). As a way of sharing the advances in the studies of the Business Games, several national and international associations began to appear in the 1970s, holding periodic meetings all over the world (Sauaia, 1995).

From the introduction to the academic universe, which took place in 1957 by the University of Washington, business games proved to be a "full, cognitive and affective learning technique, in the area of Administration and Business". Since then, the use has been quite intense, with the peak of use in the academic environment occurring in the 1980s. At that time, more than 1900 colleges of Business and Business and more than 9000 teachers used this educational tool (Sauaia, 1995, p. 13).

In Brazil, however, the introduction of this type of technique only occurred in the 1970 s and in a less remarkable way than the United States. Only a few of the major faculties of business started to adopt business games on a regular basis as an educational tool, namely: Faculty of Economics, Administration and Accounting at the University of São Paulo (FEA-USP); São Paulo School of Business Administration, Fundação Getúlio Vargas (EAESP); Business Faculties of the Pontifical Catholic University (PUC), University of Rio de Janeiro (UFRJ), Federal University of Rio Grande do Sul (UFRGS) (Sauaia, 1995).

For Santos (2003, p. 83), business games can be defined as "Simplified mathematical abstractions of a situation related to the business world". In this, the participants assume the role of administrators of the fictitious company and are responsible for decision making, either individually or in teams for the smooth operation of the simulated company.

Martinelli (1988) adds that company games have as main purpose to prepare the participant or student, through a hypothetical business case, for future professional activity by inserting in a simulated decision-making environment at the company's top management level. For this author "a great advantage of business games as a didactic and training tool is their purpose of 'speeding up time', making several years of experience compress in a few days (or even hours)" (p. 26).

Santos (2003), referring to Tanabe (1977 apud Santos, 2003, p. 83), who was one of the pioneers in the study of corporate games in Brazil, describes that there are four basic characteristics in any corporate game, namely: "[...] it has a simulated environment; all decision variables are expressed in the model; develops interactions between participants and the simulated object; it is always simpler than the real world".

Despite the widespread use by large companies and colleges around the world, the effectiveness of using Business Games is still controversial. Many scholars claim that there is no conclusive evidence that this is a superior technique over other traditional teaching methods. These same authors claim that despite the absence of evidence, the use of Business Games to aid teaching can, in theory, be a very effective and superior form of teaching (Martinelli, 1988; Santos, 2003; Sauaia, 1995).

\subsubsection{Simulation}

There are situations in which the best way to train people is through simulation. "The simulation is a situation in which a simulated scenario represents the real models, allowing the reproduction of everyday life". The need to use the simulation can be due to financial reasons or the risks involved with the activity. As an example, we have the preparation of an airplane pilot or an astronaut, which is done through the use of simulators, because in a real situation it involves high costs and high risks (Gramigna, 2007a, p. 5). 
Researcher Mário Tanabe, in a pioneering work in Brazil, prepared a study on business games. In this study he differentiates Business Games from Simulation and Game Theory, as shown in Table 1 (Santos, 2003).

Table 1. Differences between Game Theory, Simulation and Business Games.

\begin{tabular}{|c|c|c|c|}
\hline ITEM & GAME THEORY & SIMULATION & BUSSINESS GAMES \\
\hline What it is & $\begin{array}{l}\text { A theory that seeks to } \\
\text { explain the behavior of } \\
\text { economic agents in } \\
\text { conflict situations. }\end{array}$ & $\begin{array}{l}\text { Numerical technique for } \\
\text { solving problems through } \\
\text { experiments with a model } \\
\text { of the real situation. }\end{array}$ & $\begin{array}{l}\text { Sequential decision- } \\
\text { making exercise, } \\
\text { structured around a } \\
\text { business simulation } \\
\text { model, in which } \\
\text { participants take on the } \\
\text { task of managing the } \\
\text { simulated companies. }\end{array}$ \\
\hline Purpose & $\begin{array}{l}\text { Reach general } \\
\text { conclusions }\end{array}$ & $\begin{array}{l}\text { Obtain specific solutions } \\
\text { for each particular } \\
\text { problem. }\end{array}$ & $\begin{array}{l}\text { Training of participants: } \\
\text { teaching techniques and } \\
\text { scenarios by means of } \\
\text { observing behaviors. }\end{array}$ \\
\hline Methods & $\begin{array}{c}\text { Reduce real situations to } \\
\text { the situation of a strategic } \\
\text { game; seek the } \\
\text { mathematical solution of } \\
\text { the corresponding game } \\
\text { situation. }\end{array}$ & $\begin{array}{l}\text { Formulate the real } \\
\text { problem in terms of a } \\
\text { model; obtain solutions by } \\
\text { manipulating the model; } \\
\text { apply the conclusions to } \\
\text { the real system. }\end{array}$ & $\begin{array}{l}\text { Data and model and } \\
\text { objective, make } \\
\text { participants interact } \\
\text { through it; observe the } \\
\text { targeted behavior or } \\
\text { training; evaluate the } \\
\text { results. }\end{array}$ \\
\hline
\end{tabular}

Source: Tanabe (1977 apud Santos, 2003, p. 83).

A great advantage of simulation is that the individual being trained can repeat a simulation as many times as necessary until the performance is satisfactory. This feature allowed widespread use and simulation today (Gramigna, 2007a). A clear example regarding the use of simulators is provided in Resolution No. 543 of July 15, 2015 of the National Traffic Council (CONTRAN), which obliges new applicants for a driver's license to undergo training in driving simulators before taking to the automobile classes (Brasil, 2015).

For Santos (2003), every game of companies can be considered a simulation, since it ends up being a simplified model of reality, and in that way it will never be perfect, because reality has countless and complex variables that end up being unfeasible or impossible to be represented on a model.

\subsubsection{Serious games}

The use of the term 'business games', when used as a teaching and training tool, can generate a somewhat distorted connotation of the real purpose, as exposed by Martinelli (1988, p. 26):

It should be noted, however, regarding the use of company games as a training tool, that we must take certain precautions when using games for this purpose. There is a risk that participants will consider the game as a game (including the term 'business game' itself, in some cases, may lead to this problem).

Santos (2003) corroborates this thinking when he states that "[...] the name 'game of companies' can give a connotation that the activity is just 'play' without purpose, an activity to pass the time and not a 'business simulation'" (Santos, 2003, p. 83). 
For Alves (2013), not all games exist only for the purpose of entertaining and entertaining the player. Some have the purpose of transmitting educational content. These began to be designated, from the 1980s, as Serious Games. The term, in its essence, came to designate the use of games with pedagogical purposes, in order to transmit information in a more pleasant and effective way.

Alves (2013, p. 6) adds that serious games "[...] then serve to combat students' demotivation regarding boring student practices and thus obtain better results". These are usually linked to areas such as defense, education, scientific exploration, health, engineering, among others.

For Djaouti et al. (2011), the term Serious Games, appeared in 1970, from the seminal work of the North American researcher Clark Abt, in the book Serious Games. The book aimed to discuss and use games for training and education. Abt, from there, makes a clear definition for Serious Games,

[...] games can be played seriously or casually. We are concerned with 'Serious games', in the sense that these games have an explicit and carefully thought out educational purpose and are not intended to be played primarily for fun. This does not mean that the serious game is not, or should not be, fun. (Abt, 1987, p. 9).

This same author adds that serious games offer us a rich field for an active exploration of the most diverse areas of activity, without risk, of intellectual and social problems. "The interpretation of roles that students play in games that simulate life is an excellent preparation for the real roles that they will play in society later" (Abt, 1987, p. 14).

Alves (2013) adds that serious games can be used for the most diverse purposes, including political, advertising, economic, environmental or humanitarian causes, among others.

Table 2 shows a comparison between traditional training, practical training and game-based learning.

Table 2. Comparison between traditional training, practical and learning based on games.

\begin{tabular}{cccc}
\hline ITEM OF COMPARISON & $\begin{array}{c}\text { TRADITIONAL } \\
\text { TRAINING }\end{array}$ & $\begin{array}{c}\text { PRACTICAL } \\
\text { TRAINING }\end{array}$ & $\begin{array}{c}\text { GAME-BASED } \\
\text { LEARNING }\end{array}$ \\
\hline Economic viability & $\mathrm{X}$ & & $\mathrm{X}$ \\
\hline $\begin{array}{c}\text { Low physical hazard / } \\
\text { responsibility }\end{array}$ & $\mathrm{X}$ & $\mathrm{X}$ \\
\hline $\begin{array}{c}\text { Standardized assessments } \\
\text { using student-student } \\
\text { comparison }\end{array}$ & $\mathrm{X}$ & $\mathrm{X}$ & $\mathrm{X}$ \\
\hline $\begin{array}{c}\text { Constant involvement } \\
\text { Tailored learning pace for } \\
\text { individual student }\end{array}$ & $\mathrm{X}$ & $\mathrm{X}$ \\
\hline $\begin{array}{c}\text { Immediate feedback in } \\
\text { response to students }\end{array}$ & $\mathrm{X}$ & $\mathrm{X}$ \\
\hline $\begin{array}{c}\text { Student can easily transfer } \\
\text { learning to the real world }\end{array}$ & $\mathrm{X}$ & $\mathrm{X}$ \\
\hline $\begin{array}{c}\text { The student is actively } \\
\text { engaged }\end{array}$ & $\mathrm{X}$ & $\mathrm{X}$ \\
\hline
\end{tabular}

Source: Adapted from Trybus (2009).

Based on the information in Table 2, it can be seen that Game-based Learning (GBL) is the type of serious game that most relates to the objectives of this work, that is, with the improvement of the teaching-learning process, for example, using games. Another important point is the effectiveness of game-based learning; in this context, serious 
games. Table 2 shows that Game-based Learning (GBL) combines the advantages of traditional model with those of practical training. In this regard, when well developed, games add advantages of traditional, theoretical teaching, with practical activities, besides making studying with the assistance of games a fun and practical activity.

\subsubsection{Gamification}

The concept of gamification can mean different things depending on the context to which it refers (Ramirez \& Squire, 2015). More broadly and commonly accepted, gamification means "the use of game design elements in contexts not related to games" (Walz \& Deterding, 2015). When used in a business context, gamification is the process of integrating game dynamics or using game elements on websites, business services, online communities, content portals, or marketing campaigns to drive and motivate people. people to participation, involvement, engagement and loyalty, using the same techniques that game designers use to engage and hold players attention in electronic games (Bunchball Inc., 2010).

The term 'gamification' originated in the digital media industry. The first documented reports of use date back to 2008, but widespread adoption only occurred in 2010 with the popularization of games and the beginning of conferences dedicated to the theme. Despite the recent use of the term, the idea behind the concept was already addressed in the literature, such as 'playful interaction design' or in the Portuguese 'design de interação lúdica' (Deterding et al., 2011). For Américo \& Navari (2013) the use of the term 'gamification' is recent, the first search appeared on the sites dedicated to this purpose in September 2010 and only in August 2012 was the first search for the term 'gamification' carried out.

For Walz \& Deterding (2015) gamification emerged to overcome serious games and the first project within the new movement was Foursquare, launched in 2009, it is a mobile social service based on the user's location, which has become a model for other games.

The success stories of the sector do not stop, there are several companies around the world that increasingly use gamification as an incentive to use products or services. In 2008, Nike, a global clothing and footwear manufacturer, launched Nike + , where a data capture application installed on a mobile device recorded data such as distance, pace and calories burned. Users earned rewards for completing challenges or when breaking their own records and after each workout, you could follow the statistics of the activity practiced and follow the progress of other users (Bunchball Inc., 2010).

The well-known Mileage Programs offered by airlines are also based on gamification. The program is based on the accumulation of miles (points) for each air travel that the user makes and the more trips the more points are accumulated. These points can be exchanged for prizes, discounts, airline tickets, among others (Bunchball Inc, 2010).

Mattar (2010) considers the need to adopt new teaching strategies. Education today is brutally segmented. At school, the student learns contents that are out of context of the practical application, being obliged to passively and individually decorate themes that do not make sense and in this case the retention of knowledge is low, as they cannot visualize an application for this knowledge. In games, learning is given through simulations, where the player helps in a collaborative and active way to build knowledge and in addition, gamification can help students engage with the outdated education system.

Fardo (2013) adds that gamification can promote learning, since many elements used are based on the techniques that teachers have long used, such as distribution of points for activities, feedback and encouragement to carry out collaborative projects. What differentiates the practices adopted with gamification is the explanation of the methods so that they are similar to games, that is, in a language that young people are more familiar 
with and thus more efficient results can be achieved. Furthermore, the cooperative nature of games enhances problem solving, as it is able to focus the attention of several students on solving a challenge, encouraging them to do their best to win the game.

\subsection{Bibliometrics as a research tool}

Bibliometric methods use the quantitative approach to describe, evaluate and monitor research that has already been published on a given subject. "Bibliometric methods are a useful aid in literature reviews, even before reading begins by the researcher, he already identifies the most influential works and maps the research field without subjective bias" (Zupic \& Čater, 2015, p. 431). This review process, through bibliometric studies, has the power to improve the quality of reviews.

\subsubsection{Bibliometric methods}

Bibliometric methods are characterized by two main uses: performance analysis and science mapping. The first assesses the performance of authors, institutions and publications, while the second seeks to reveal the structure and dynamics of scientific fields (Cobo et al., 2011; Zupic \& Čater, 2015).

Zupic \& Čater (2015) complement that the five main bibliometric methods are: Citation, co-citation, bibliographic coupling, co-author, and co-word. The first three can be seen as measures of influence and similarity; co-author analysis uses co-author data to measure collaboration between authors; while the co-word indicates the connections between concepts, whether in titles, keywords or abstracts.

These five methods are described in Table 3.

Table 3. Bibliometric Techniques.

\begin{tabular}{|c|c|c|c|}
\hline TECHNIQUE & UNIT IN ANALYSIS & DESCRIPTION & TYPE OF RELATION \\
\hline \multirow{3}{*}{ Citation } & Author & \multirow{3}{*}{$\begin{array}{c}\text { Estimates the influence of } \\
\text { documents, authors or magazines } \\
\text { through citation rates. }\end{array}$} & \\
\hline & Document & & \\
\hline & Periodical & & \\
\hline \multirow{4}{*}{$\begin{array}{l}\text { Bibliographic } \\
\text { Coupling }\end{array}$} & Author & \multirow{4}{*}{$\begin{array}{l}\text { Connects documents, authors or } \\
\text { magazines according to the } \\
\text { number of shared references. }\end{array}$} & References: \\
\hline & Document & & $\begin{array}{l}\text { Common among the } \\
\text { author's works; }\end{array}$ \\
\hline & \multirow{2}{*}{ Periodical } & & $\begin{array}{l}\text { Common between } \\
\text { documents; }\end{array}$ \\
\hline & & & $\begin{array}{l}\text { Common among the } \\
\text { magazine's works. }\end{array}$ \\
\hline \multirow{3}{*}{ Co-author } & Author & \multirow{3}{*}{$\begin{array}{c}\text { Connects authors when they are } \\
\text { co-authors of one or more } \\
\text { articles. }\end{array}$} & $\begin{array}{l}\text { Co-occurrence of the } \\
\text { authors }\end{array}$ \\
\hline & Country & & Countries co-occurring \\
\hline & Institution & & $\begin{array}{l}\text { Co-occurrence of } \\
\text { institutions }\end{array}$ \\
\hline \multirow{3}{*}{ Co-citation } & Author & \multirow{3}{*}{$\begin{array}{l}\text { Connects documents, authors or } \\
\text { journals based on joint } \\
\text { appearances in the reference } \\
\text { lists. }\end{array}$} & Authors cited along \\
\hline & Work & & Works cited along \\
\hline & Periodical & & Journals cited along \\
\hline Co-word & $\begin{array}{l}\text { Keywords or term } \\
\text { extracted from the } \\
\text { title, abstract or body } \\
\text { of document }\end{array}$ & $\begin{array}{c}\text { Connects keywords when they } \\
\text { appear in the same title, summary, } \\
\text { or keyword list. }\end{array}$ & $\begin{array}{l}\text { Simultaneous occurrence } \\
\text { of two terms }\end{array}$ \\
\hline
\end{tabular}

Source: Adapted from Cobo et al. (2011); Zupic \& Čater (2015). 
From the definitions of Bibliographic Coupling and Co-citation, it is necessary to distinguish between the two concepts. Bibliographic Coupling happens when, for example, an ' $A$ ' article and an ' $B$ ' article quote the same ' $C$ ', ' $D$ ' and ' $E$ ' articles, thus ' $A$ ' and 'B' articles are coupled. Thus, the bibliographic coupling occurs when two articles refer to at least one publication in common, that is, the bibliographic coupling establishes a connection between two articles when using the same references. Co-citation occurs when several articles together cite two or more articles, for example, articles ' $A$ ' and ' $B$ ' appear together in articles 'C', 'D' and ' $E$ ', that is, articles 'A' and 'B' are mentioned in the articles ' $C$ ', ' $D$ ' and ' $E$ ' (Cobo et al., 2011; Ferreira, 2018; Grácio, 2016; Zupic \& Čater, 2015).

Contrary to the bibliographic coupling that links / resembles documents, through their common citations, the quotation identifies the connection / similarity of two documents mentioned, via their frequencies of joint occurrence in a list of references of the citing authors (Grácio, 2016, p. 88).

Figure 1 shows the differences between the two concepts

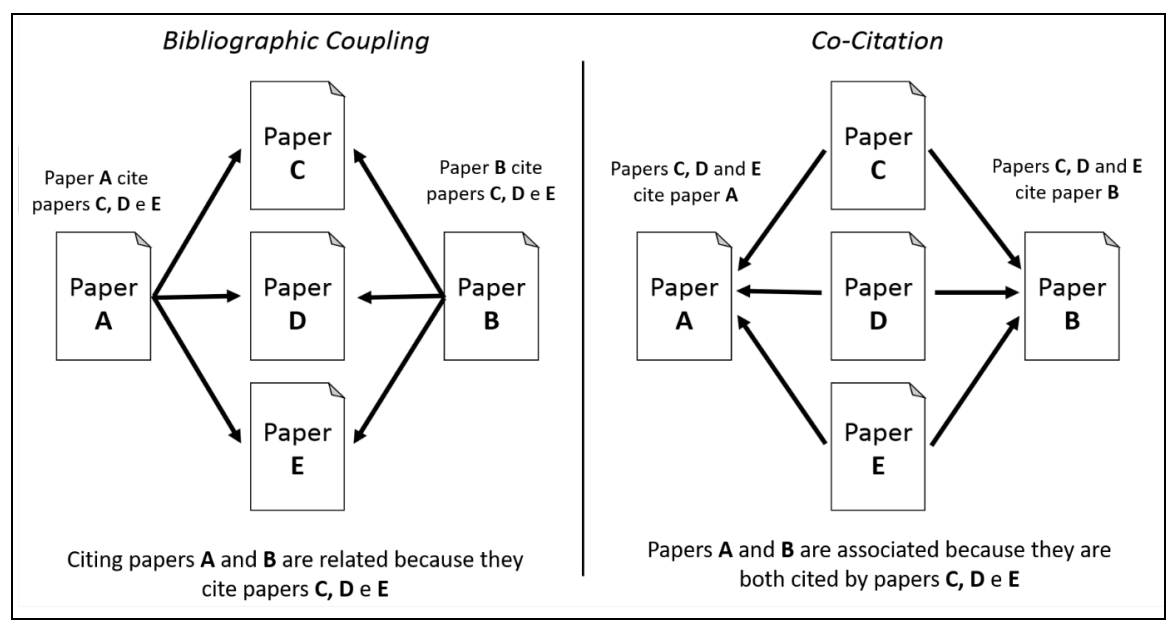

Figure 1. Differences between Bibliographic Coupling e Co-citation. Source: Adapted (Cobo et al., 2011; Ferreira, 2018; Grácio, 2016; Zupic \& Čater, 2015).

To carry out bibliometric analysis, there are several software on the market to facilitate the work. In this research, the VOSViewer software will be used, which besides being free is easy to use. According to van Eck \& Waltman (2010), VOSViewer is a tool for visualization and construction of bibliometric maps. After obtaining data from the network, the information is compiled and exported in a format compatible with the software and from there can be analyzed. Several characteristics of the database can be explored in form of maps, such as: keyword maps, bibliographic coupling, co-occurrence of citations, most cited authors, among several other features.

\section{Methodological procedures}

Based on the theoretical framework, a bibliometric survey of the last 10 years will be carried out in the annals of ENEGEP. Priority will be given to the terms 'game', which will automatically include in the results, if any, the words games, business games, serious games, educational games and game-based teaching, in addition to the search for the word gamification. The corresponding terms in Portuguese will also be searched. 
The National Meeting of Production Engineering - ENEGEP, had first taken place in 1981, and since 1986 it is promoted annually by the Brazilian Association of Production Engineering - ABEPRO. In the last year (2017), more than 1,300 papers were published (ABEPRO, 2018). The bibliometric survey is carried out in the annals of this event due to its importance and quantity of works available for research.

After the result of the research, graphs and tables will be constructed in order to demonstrate the use of games to improve the teaching-learning process of the proposed subjects. To help visualize and understand the concepts involved and used by Zupic \& Čater (2015) - citation, bibliographic Coupling, co-author, co-citation and co-word, the VOSViewer software will be used, which in addition to being free is easy use. In this way, maps will be explored from the databases that will be useful to visualize the most used keywords, the bibliographic coupling, the co-occurrence of citations, the most cited authors, among several other useful information for the work.

\section{Results and discussion}

\subsection{Bibliometric research on the use of games in the annals of ENEGEP}

We then proceed to the bibliometric survey in the annals of the National Meeting of Production Engineering - ENEGEP in order to seek out how the development of scientific publications of games has been in the context of Production Engineering, especially with regard to the areas of Quality Management and Production Management. For this survey, a search was made for publications in the annals using the word 'jogo' (game).

This search was carried out between July 25 and September 25, 2018 on ENEGEP website in the publications section in the Job Search tab, option 'Evento: (Event)' initially filled in with '2008- ENEGEP', '2009-ENEGEP', and so on until 2017 (10 years - time frame). The 'Área: (Area)' and 'Autor: (Author)' options have been left blank. In the 'Search:' option, the word 'jogo' (game) was inserted. In other words, articles that contain the term 'jogo' (game) and automatically its plural 'jogos' (games) were searched in the title, summary or keywords, as well as 'jogos de empresas' (business games) and 'jogos sérios' (serious games). No results were found for the words 'gamificação' (gamification), gamification and serious games.

From there, the titles and abstracts of the articles presented in the results were read and those outside the research objectives were discarded, such as those related to games in sports tournaments, statistics in games of chance, logistics in the Olympic games held in the Brazil, among others.

Initially 97 articles from the last 10 years were found. After the disposal of those out of scope, 46 documents remained. These 46 works were then downloaded and an Excel file was created containing the title, authors, affiliation, summary, year and references used. This Excel file was created along the same lines as those exported by the Scopus database and which are used to create maps in VOSViewer.

At that moment, the first difficulty appears, because unlike what happens in these other cited databases, in which the Excel file containing the articles of interest is easily exported to various formats compatible with bibliometric software, in the annals of ENEGEP there is no such option. In this way, the articles have to be downloaded from the website one by one, and then the information of interest is copied to a data sheet.

Another point to be addressed is the lack of rigor in relation to the use of technical standards on bibliographic references by the authors of the analyzed works. The 
Vosviewer software has errors when reading the spreadsheet with references that are not properly standardized and in accordance with international standards. An example is the use of the term 'et.al.' when there are more than 3 authors in the work, a fact that compromises the performance of a more accurate analysis, since many authors may appear as co-authors in the works and their names not included in the reference lists.

To try to minimize these problems and so that Vosviewer could read the file, the information in the spreadsheet had to be carefully formatted. All types of accentuation of words were removed, replacing 'Ç' with ' $\mathrm{C}$ ', after the name of each author, a period was inserted and then a comma '.,' (For the software to understand that this is another author), after each reference used the comma point ';' (to separate one from the other), the 'et. al.' of the references (for the software does not understand that it is an author with that name) and also created a file to replace the names of the authors (for example: the author Gramigna is spelled as Gramigna, MRM and Gramigna, MR, so the program understands to be two distinct authors).

The result of the survey in each year is shown in Table 4.

Table 4. Compilation of result of the survey in ENEGEP proceedings - 2008 a 2017.

\begin{tabular}{cccccccccccc}
\hline ITEM & 2008 & 2009 & 2010 & 2011 & 2012 & 2013 & 2014 & 2015 & 2016 & 2017 & TOTAL \\
\hline $\begin{array}{c}\text { Searches } \\
\text { for 'jogo' } \\
\text { (game) }\end{array}$ & 5 & 9 & 17 & 10 & 5 & 8 & 13 & 4 & 15 & 11 & 97 \\
\hline $\begin{array}{c}\text { Files } \\
\text { within the } \\
\text { scope }\end{array}$ & 2 & 5 & 9 & 6 & 3 & 2 & 5 & 2 & 6 & 6 & 46 \\
\hline $\begin{array}{c}\text { Total } \\
\text { amount } \\
\text { of } \\
\text { published } \\
\text { articles }\end{array}$ & 945 & 788 & 1.366 & 1.072 & 1.035 & 832 & 1.009 & 1.062 & 1.118 & 1.301 & 10.528 \\
\hline
\end{tabular}

Source: Author (2018).

Figure 2 shows the number of articles that are within the scope of the work in each year, from 2008 to 2017.

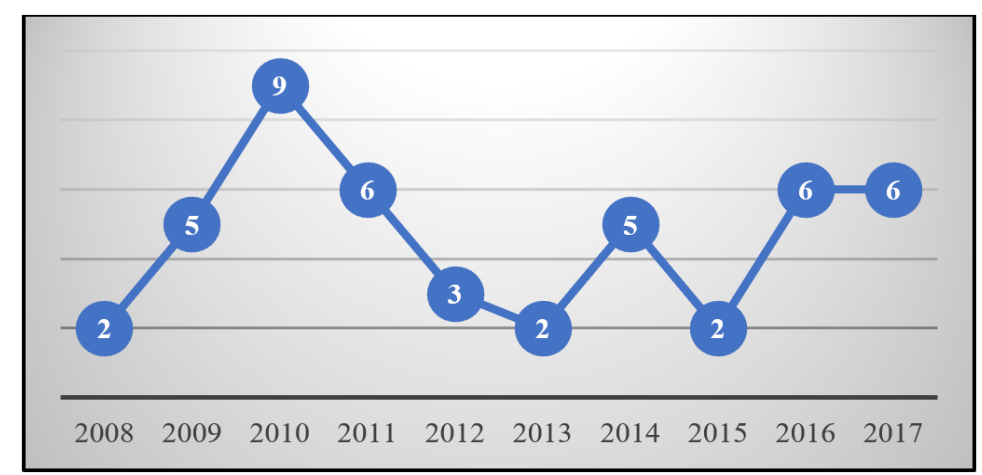

Figure 2. Number of works on games from 2008 to 2017. Source: Author (2018).

It can be seen that the amount of works published in the event that are related to games does not vary greatly. Thus, there is no way to affirm that there is more or less interest in the subject over time. 
Using the citation technique, the authors and institutions that produced the most in the researched area are identified. Table 5 shows the institutions with the largest number of studies on use of games for educational purposes from 2008 to 2017.

Table 5. Institutions with the largest number of works on games from 2008 to 2017 (citation).

\begin{tabular}{ccc}
\hline INITIALS & INSTITUTIONS & TOTAL \\
\hline UNESP & Universidade Estadual Paulista & 7 \\
\hline UFSCAR & Universidade Federal de São Carlos & 4 \\
\hline UNIFEI & Universidade Federal de Itajubá & 4 \\
\hline UNINOVE & Universidade Nove de Julho & 3 \\
\hline CEFET/RJ & Centro Federal de Educação Tecnológica Celso Suckow da & 2 \\
\hline IFES & Fonseca & 2 \\
\hline UDESC & Instituto Federal do Espírito Santo & 2 \\
\hline UFRJ & Universidade do Estado de Santa Catarina & 2 \\
\hline UFSC & Universidade Federal do Rio de Janeiro & 2 \\
\hline UFSM & Universidade Federal de Santa Catarina & 2
\end{tabular}

Source: Author (2018).

It is worth noting the large production of works on the Southeast-South axis, where the institutions that most produced works on games in Production Engineering are located.

Table 6 shows the authors and their affiliations (institution to which they belong) and the number of works that the author published on games between 2008 and 2017 on ENEGEP.

Table 6. Scientific production of authors on games at ENEGEP between 2008 and 2017 (citation).

\begin{tabular}{ccc}
\hline AUTHOR & AUTHOR'S MEMBERSHIP & $\begin{array}{c}\text { NUMBER OF } \\
\text { WORKS }\end{array}$ \\
\hline Rodrigues, José de Souza & UNESP - Universidade Estadual Paulista & 5 \\
\hline Campos, Renato de & UNESP - Universidade Estadual Paulista & 4 \\
\hline Pallone, Flávio Valério & UNESP - Universidade Estadual Paulista & 3 \\
\hline Mantelato, Beatriz & UNESP - Universidade Estadual Paulista & 3 \\
\hline Maekawa, Rafael Teruo & UNESP - Universidade Estadual Paulista & 3 \\
\hline Có, Fábio Almeida & IFES - Instituto Federal do Espírito Santo & 3 \\
\hline Talamonte, Isabella Pinho & UNESP - Universidade Estadual Paulista & 2 \\
\hline Silva, Carlos Eduardo & UNIFEI - Universidade Federal de Itajubá & 2 \\
Sanches da & UFSM - Universidade Federal de Santa & 2 \\
\hline Ribeiro, Roberto Portes & Maria \\
\hline Piana, Janaína & UFSC - Universidade Federal de Santa & 2 \\
\hline
\end{tabular}

Source: Author (2018).

The number of works by each author in Table 3 does not necessarily represent the appearance as the first author of the work. In this way, UNESP appears as the affiliation of several authors, but they are co-authors of the same works, that is, they are authors who usually work together. 
The first analysis carried out with the support of Vosviewer software was coauthorship-wise. Figure 3 shows the co-authorship map, that is, it shows which authors develop research together.

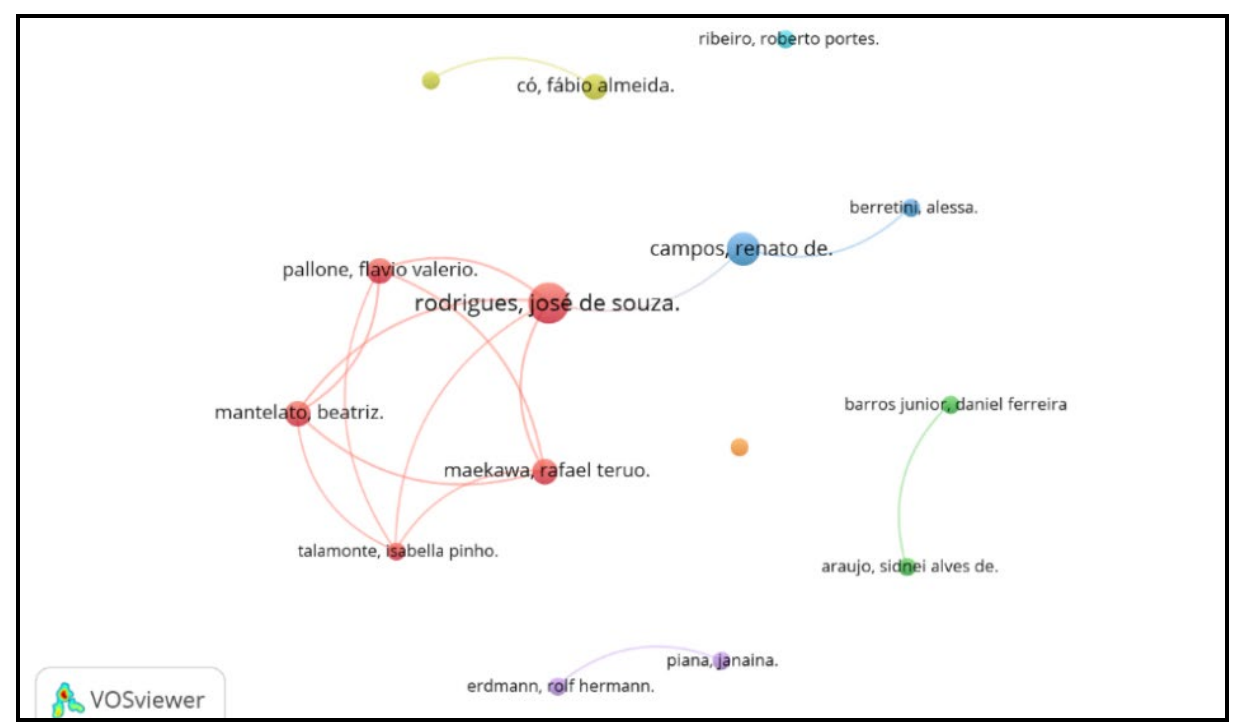

Figure 3. Map of co-authorship of the main authors in the period between 2008 and 2017 (co- author). Source: Author (2018).

Each color shown on the map indicates a cluster, which is a group or agglomerate that maintains a certain connection. In such a way, each color indicates a group of researchers who work together, thus developing researches in the same area. The size of the circles and the characters in the authors' names indicate the amount of work by that author. Larger circles indicate more work. The distance between the circles indicates approximation of the co-authorship relationship and the lines the reveal connections between the authors. Clusters located close to each other indicate closely related fields (van Eck \& Waltman, 2017).

Analyzing the co-authorship, the presence of 112 authors is verified in all 46 analyzed works. For a better visualization of the information, it was configured to display authors who have more than 2 documents with a co-authorship relationship, which generated a map with 15 results, but with only 13 presenting relations.

From the map, the presence of 5 clusters or set of authors that maintain some co- authorship relationship is verified, being represented by the colors: red - Rodrigues, Pallone, Mantelato, Maekawa, Talamonte; green - Barros Júnior and Araújo; yellow - Có and Lavagnoli; blue - Campos and Berretini; purple - Piana and Erdmann. Furthermore, the relationship between Rodrigues and Campos is clear, even though they are in different clusters. All the relationships presented are co- authored in works by authors from the same institution, that is, there are no authors with more than two works regarding theme of games, who are from different institutions and who have published works together.

The next analysis was that of co-word or keywords that appeared most in the search results. At that moment, only the words that the authors used in the 'keyword' or keyword field were computed. The words are shown in Table 7. 
Table 7. Keywords with higher occurrence in works between 2008 and 2017 (co-word).

\begin{tabular}{cc}
\hline WORD & TOTAL \\
\hline Jogos de empresas (Business games) & 14 \\
\hline Simulação (Simulation) & 7 \\
\hline Ensino (Teaching) & 5 \\
\hline Jogos (Games) & 5 \\
\hline Aprendizagem (Learning) & 5 \\
\hline Engenharia de Produção (Production Engineering) & 4 \\
\hline Gestão da Produção (Production management) & 3 \\
\hline Dinâmica de ensino (Teaching dynamics) & 3 \\
\hline Ensino aprendizagem (Teaching-learning) & 3 \\
\hline Jogos educacionais (Educational games) & 3
\end{tabular}

Source: Author (2018).

Vosviewer does not distinguish between words with different spellings, even if they are words in the singular or plural. Therefore, words such as businesses games / business games, teaching-learning / teaching learning, teaching in production engineering / teaching of production engineering, among others, were gathered into a single term of reference. For a better visualization of the keywords and their relationships, Figure 4 is presented.

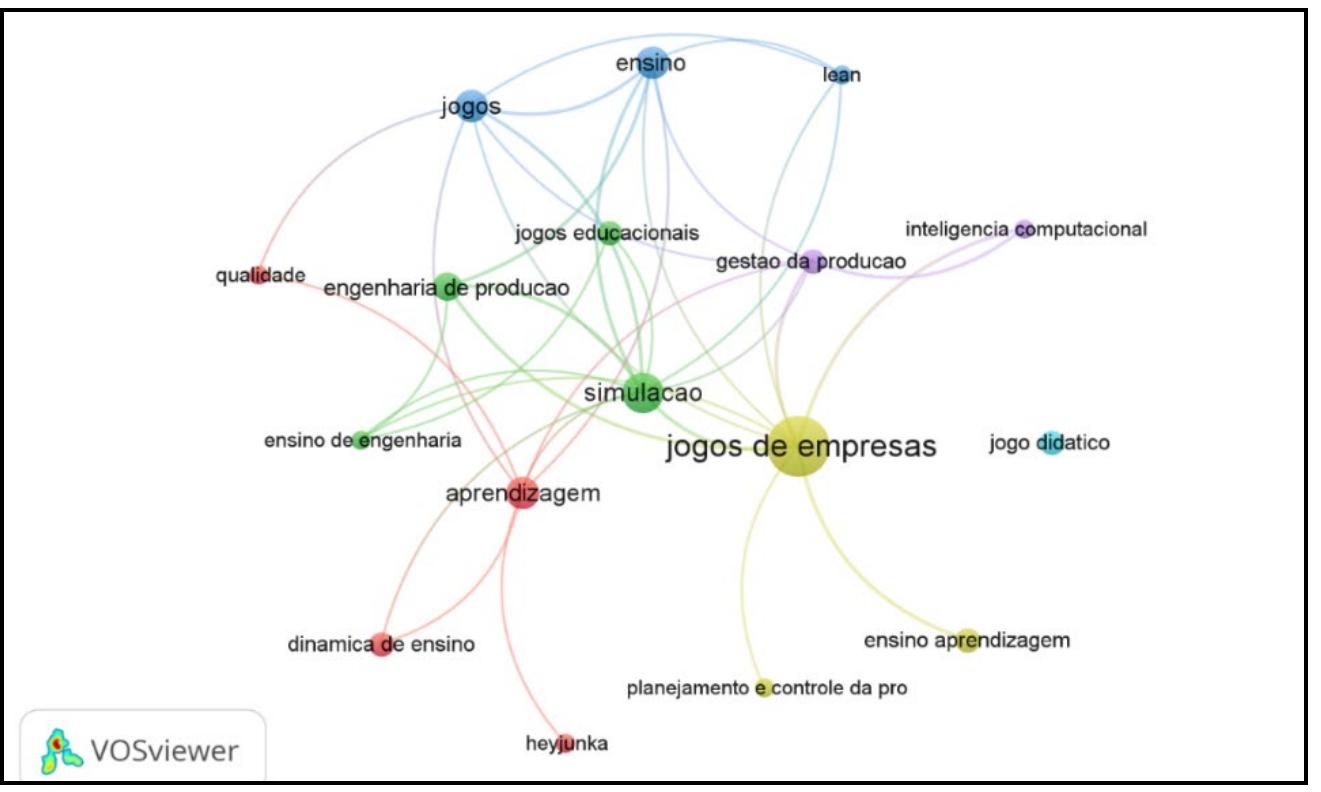

Figure 4. Map of keywords with the highest occurrence of jobs between 2008 and 2017 (co-word). Source: Author (2018).

Five main clusters are displayed and they are represented by the colors: yellow - with the main keyword 'business games' linked to 'teaching learning' and 'production planning and control'; green - term 'simulation' linked to the terms 'educational games', 'engineering education' and 'production engineering'; blue - term 'games' linked to the terms 'teaching' and 'lean'; red - with the main keyword 'learning' that is linked to the terms 'teaching dynamics', 'heyjunka' and 'quality'; purple - term 'production management' linked to the word 'computational intelligence'. There are also terms that link to words belonging to 
other clusters, as there is a relationship between these among the keywords presented by the authors of the analyzed studies.

The reported clusters are overlapping, which indicates a strong relationship between them. The size of the circle indicates the importance of the word and the lines connecting one circle to the other indicate that there is a link in the use of words between the works.

It is important to highlight the word 'production management' strongly related to 'business games', 'simulation', 'learning', 'games', 'teaching' and 'computational intelligence'. The word 'quality' linked to 'games' and 'learning', 'production engineering' linked to 'teaching', 'engineering teaching', 'simulation' and 'business games'.

In ENEGEP there are no works that use the terms 'gamification', 'serious games', 'game-based learning' and 'game-based teaching' which are newer terms and are in evidence in the academic environment in relation to the use of games for learning. It is also noticed that the Brazilian authors, who publish in ENEGEP, continue to use the terms 'company games' and 'educational games', terms that have been replaced by researchers around the world. These facts can be explained by a delay of national researchers (those who publish in ENEGEP) when compared to the world literature.

In the co-citation analyzes, where the joint appearances in the reference lists are connected, 890 occurrences of authors and 703 works cited in the 46 analyzed documents are observed. Table 8 shows the most cited authors in the studies analyzed with the cocitation method.

Table 8. Most cited authors in works between 2008 and 2017 (co-citation).

\begin{tabular}{|c|c|c|}
\hline AUTHOR & FIELDS OF THE CITED WORKS & TOTAL \\
\hline $\begin{array}{l}\text { Sauaia, Antonio } \\
\text { Carlos Aidar }\end{array}$ & Business games & 24 \\
\hline Gramigna, Maria Rita & Business games & 15 \\
\hline Campos, Renato de & Simulation and games & 11 \\
\hline $\begin{array}{c}\text { Santos, Débora de } \\
\text { Gois }\end{array}$ & Didactic games for teaching lean production & 8 \\
\hline Tubino, Dálvio Ferrari & Planning and Production Control & 8 \\
\hline $\begin{array}{c}\text { Rodrigues, José de } \\
\text { Souza }\end{array}$ & Business games & 8 \\
\hline Shingo, Shigeo & Toyota Production System & 7 \\
\hline $\begin{array}{l}\text { Dorneles, Juliana } \\
\text { Bonacorso }\end{array}$ & Didactic games for teaching lean production & 6 \\
\hline Liker, Jeffrey & Toyota Management Model & 6 \\
\hline Goldratt, Eliyahu M. & Continuous Improvement & 6 \\
\hline $\begin{array}{l}\text { Costa, Adolfo C. } \\
\text { Figueiredo }\end{array}$ & Didactic games for teaching lean production & 5 \\
\hline Leal, Fabiano & Games for teaching Production Engineering concepts & 5 \\
\hline $\begin{array}{c}\text { Almeida, Dagoberto } \\
\text { Alves de }\end{array}$ & Failure mapping & 5 \\
\hline $\begin{array}{l}\text { Schafranski, Luiz } \\
\text { Erley }\end{array}$ & Production Management Games & 5 \\
\hline Depexe, Marcelo D. & Didactic games for teaching lean production & 5 \\
\hline
\end{tabular}

Source: Author (2018).

Analyzing the most cited authors together, which for Grácio (2016) indicates that the higher the frequency of co-citation, the closer the relation between those cited, thus evidencing the similarity, complementarity, overlapping of ideas between these cited authors. It is noticed the 
small use of international authors (only the 3 underlines), but these deal with the Toyota Production System and Theory of Constraints, not being authors who are dedicated to the study of games. This fact may explain, as seen in the co-word analysis, the little use of more modern words (serious games, gamification, among others).

From the Vosviewer, the co-citation map is constructed, that is, the authors who are most cited in works and who usually appear together with other authors. The map is shown in Figure 5. For easy viewing, only authors with more than 5 appearances in the works are shown.

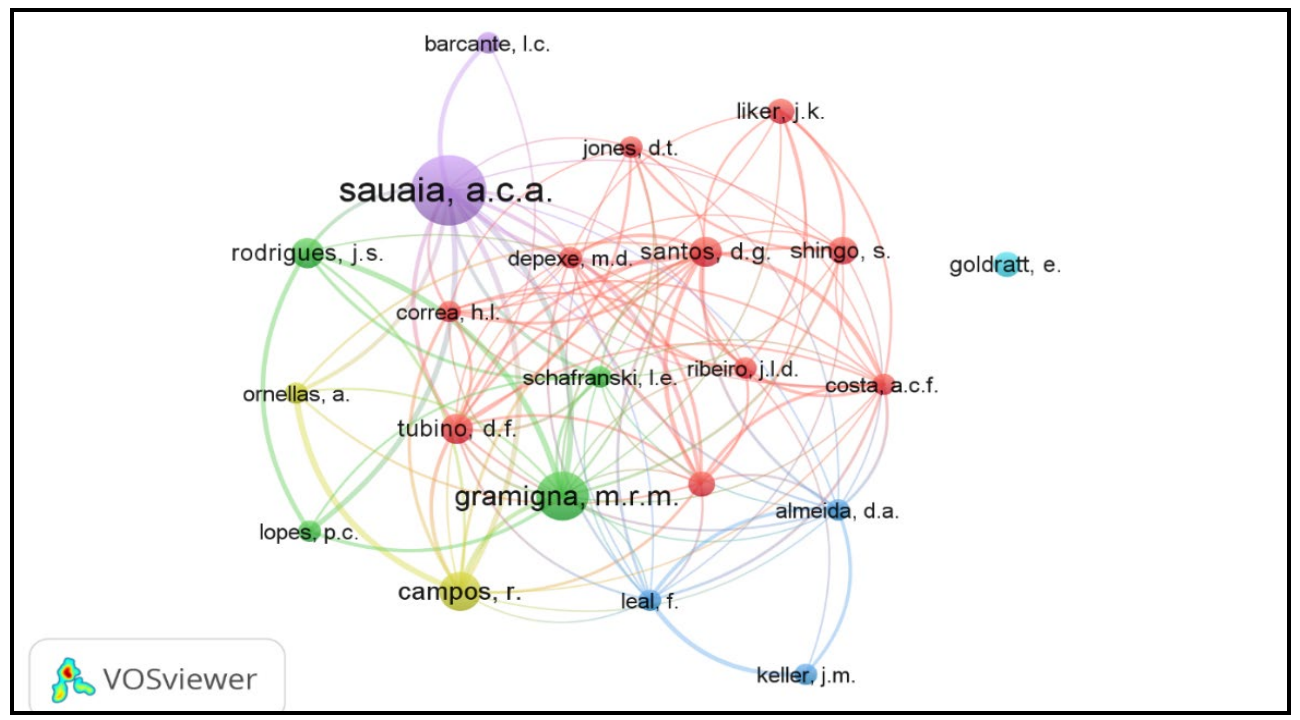

Figure 5. Map of most cited authors in works between 2008 and 2017 (co-citation). Source: Author (2018).

Each of the colors shown on the map indicates a cluster, which in the case of cocitation groups the works that usually appear together. The larger circles indicate the most cited authors and the lines represent the links between them. As shown on the map, we can see that the green cluster shows the authors Gramigna, Lopes, Rodrigues and Schafranski. In the red cluster appear Corrêa, Costa, Depexe, Dorneles, Jones, Liker, Ribeiro, Santos, Shingo and Tubino. In the blue cluster we have the authors Almeida, Keller and Leal. In the yellow cluster, Campos and Ornellas appear. Sauaia and Barcante appear in the purple cluster.

It can be seen, from the red cluster, that the reported authors usually appear together in the citation list and that they deal with issues related to Production Management, these authors being a reference in the area. Furthermore, it is noticeable the great link between this cluster with those related to corporate games (purple and green). Exactly, the authors Sauaia and Gramigna are those who produce research on business games, terms most used by the authors who cited them during the research period.

The bibliographic coupling, that is, connection between two articles when using the same references. Figure 6 shows the map with the documents that are linked bibliographically.

Only 15 documents are presented on the map, as only these maintain some kind of bibliographic coupling. Each of the clusters group documents that have some relation when analyzing the references cited by these authors. The lines represent the existence of a relation between one document and another, even if they are in another cluster. 


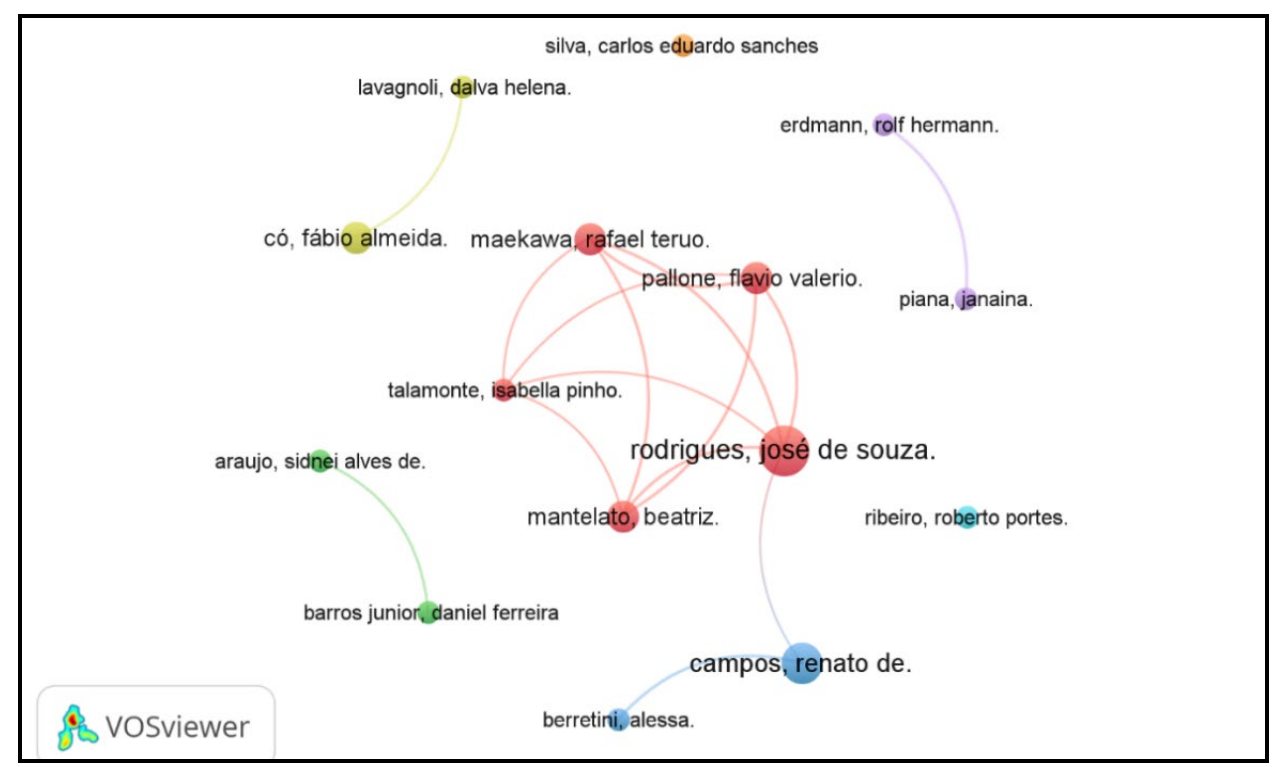

Figure 6. Map of bibliographic coupling between documents - from 2008 to 2017 (bibliographic coupling). Source: Author (2018).

Grácio (2016) considers that when using the method of bibliographic coupling, when analyzing references and authors that two scientists share in their research, a very similar theoretical and/or methodological thought is identified between these two scientists, indicating that they act in a scientific environment with great similarity.

It is possible to notice the similarity of the research by Mantelato, Rodrigues, Talamonte, Maekawa, Pallone (red cluster), who are authors who research together and who have several works in which they sometimes appear as an author, sometimes as a co-author, and thus usually use the same bibliographic references. The same behavior is observed in the blue, green, yellow and purple clusters, where these authors have more than one work together. Those authors who appear isolated (Silva and Ribeiro) is due to the fact that they have more than one work among the 46 analyzed and use common references in these documents.

Thus, the works of the authors Campos and Rodrigues, who despite having a coauthored work, have strong bibliographic coupling, as they share several references in their works. The other works, considering that they are co-authorship works, naturally there is a bibliographic coupling, since they work together and this fact by itself, already represents the common theoretical and methodological identity of these scientists.

It is noteworthy that, in this topic, only the works published in the annals of ENEGEP between the years 2008 and 2017 were analyzed. Despite being the main event for Production Engineering in the country, there are authors who prefer to submit their works in journals that have Capes Qualis evaluation, mainly the most reputable (Qualis A1, A2, B1, B2, B3, B4, B5 and C - from highest to lowest grade, in that order) since, the higher the evaluation, the greater the relevance and acceptance from the academic community. No national journal or magazine was the target of this work, since in a previous research few results were found related to the scope of the research which could compromise the results. 


\section{Conclusions}

In this study, it was proposed to map works related to the use of games in the teachinglearning process in Production Engineering, through a bibliometric study carried out in the annals of the National Meeting of Production Engineering (ENEGEP).

Thus, it was possible to know the development of the use of concepts related to games, more specifically business games, serious games, game-based learning and gamification. In addition to the concepts, it was possible to map, by the techniques of citation, bibliographic coupling, co-author, co-citation and co-word, the main bibliometric data related to institutions, authors and institutions working together, authors who are most cited together in the works and words that are most used by the authors, in addition to those that follow the same line of research.

The VOSViewer software, in this context, proved to be an important tool to facilitate the analysis of the data collected, through the construction of bibliometric maps, as it contains functions relevant to all the proposed techniques (citation, bibliographic coupling, co-author, co-citation and co-word).

Thus, it is believed that the objectives of this research have been achieved, since it was possible to carry out the bibliometric study in the way it was proposed, that is, on a national database (ENEGEP annals), limited to the years 2008 to 2017.

The analyzes carried out in the articles of the last 10 years published in ENEGEP, show an apparent delay by national researchers in the use of new designative terms for games. Terms such as gamification, serious games and game-based learning, widely used around the world, do not appear in the search results for articles published in ENEGEP. It is also noticed that Brazilian authors continue to use the terms 'corporate games' and 'educational games', terms that have been replaced by those already mentioned. These new terms are not being found in research published in ENEGEP.

Based on the research carried out in the ENEGEP annals, it is suggested that bibliometric studies be carried out in databases containing works from journals or annals that have the due rigor in accepting manuscripts, especially regarding the use of the technical standards of the Brazilian Association Technical Norms (ABNT) or other international standard, mainly regarding lists of bibliographic references. The VOSViewer software cannot read files that are not properly standardized and present different errors when performing such action. As it is software developed outside the country, it is mainly prepared for international standards, such as the American Psychological Association (APA) and Chicago Manual of Style.

The main error faced by VOSviewer in reading files built from the database of the ENEGEP annals concerns the fact that the works do not present their co-authors in the reference list, limiting them to using only the term 'et al.' when there are more than three authors at work, according to Brazilian norm. This behavior compromises the performance of a more assertive analysis, since only the first author appears in the list of references, while the co-authors are left out, despite having been important in the development of the research. This fact is different from what happens in an international database, such as the case of Scopus, in which all authors appear in the reference lists, mainly due to the use of standards in the APA format.

The number of works on the theme in the annals of ENEGEP is low, considering that this theme, its subdivisions and new concepts have been standing out in the international scenario. In the event of the year 2017, for example, six papers on the subject were found, out of a total of 1,301 documents, which represents only $0.46 \%$ of the total. It is suggested for future work to carry out the bibliometric survey in other databases, mainly those in which the Vosviewer software can read the metadata (Scopus, Pubmed and Web of 
Science) or, still, in Google Scholar Metrics, which possibly in the future you will have the option to export files for reading in the software. This may allow a more comprehensive survey, as not all magazines and conferences in the world have papers available in all databases, in many cases limiting availability on a single basis.

\section{References}

Abt, C. (1987). Serious games. New York: University Press of America.

Alves, E. (2013). Jogos sérios para ensino de engenharia de software. Porto: Universidade do Porto.

Alves, G. D. D., Boechat, F. O., \& Breda, W. L. (2017). Desenvolvimento de um jogo de tabuleiro para auxílio ao ensino superior de Engenharia de Produção. In Anais do XXXVII ENEGEP. Rio de Janeiro: ABEPRO. http://dx.doi.org/10.14488/ENEGEP2017_TN_WIC_247_427_33277.

Américo, M., \& Navari, S. C. (2013). Gamificação: abordagem e construção conceitual para aplicativos em TV digital interativa. Revista Geminis, 4(3), 87-105. Retrieved in 2018, September 25, from http://www.revistageminis.ufscar.br/index.php/geminis/article/view/163/132

Associação Brasileira de Engenharia de Produção - ABEPRO. (2001). Engenharia de Produção: Grande área e diretrizes curriculares. Retrieved in 2017, July 2, from http://www.abepro.org.br/arquivos/websites/1/DiretrCurr2001.pdf

Associação Brasileira de Engenharia de Produção - ABEPRO. (2018). ENEGEP - Encontro Nacional de Engenharia de Produção. Rio de Janeiro. Retrieved in 2018, September 25, from http://enegep2018.galoa.com.br/br/node/1268

Biasca, R. E. (2005). Resizing: reestruturando, replanejando e recriando a empresa para conseguir competitividade. São Paulo: Campus.

Brasil. Conselho Nacional de Trânsito - CONTRAN. (2015, 20 de julho). Resolução $n^{\circ}$ 543, de 15 de julho de 2015. Normas e procedimentos para a formação de condutores de veículos automotores e elétricos. Brasília, DF: Diário Oficial da República Federativa do Brasil.

Bunchball Inc. (2010). Gamification 101: an introduction to the use of game dynamics to influence behavior. Retrieved in 2018, July 12, from http://jndglobal.com/wpcontent/uploads/2011/05/gamification1011.pdf

Cobo, M. J., López-Herrera, A. G., Herrera-Viedma, E., \& Herrera, F. (2011). Science mapping software tools: Review, analysis, and cooperative study among tools. Journal of the American Society for Information Science and Technology, 62(7), 1382-1402. http://dx.doi.org/10.1002/asi.21525.

Costa, V. P., \& Silva, C. E. S. (2017). Avaliação de jogos educacionais: uma revisão teórica. In Anais do XXXVII ENEGEP. Rio de Janeiro: ABEPRO. https://doi.org/10.5753/cbie.sbie.2015.519.

Crookall, D. (2010). Serious games, debriefing, and simulation/gaming as a discipline. SAGE Journals, 41(6), 898-920. http://dx.doi.org/10.1177/1046878110390784.

Deterding, S., Khaled, R., Nacke, L. E., \& Dixon, D. (2011). Gamification: toward a definition. In CHI 2011 (pp. 12-15). Vancouver. Retrieved in 2018, September 25, from http://gamificationresearch.org/wp-content/uploads/2011/04/02-Deterding-Khaled-Nacke-Dixon.pdf

Djaouti, D., Alvarez, J., Jessel, J.-P., \& Rampnoux, O. (2011). Origins of serious games. In M. Ma, A. Oikonomou \& L. C. Jain (Eds.), Serious games and edutainment applications (pp. 25-43). London: Springer. http://dx.doi.org/10.1007/978-1-4471-2161-9_3.

Fardo, M. L. (2013). A gamificação como estratégia pedagógica: estudo de elementos dos games aplicados em processos de ensino e aprendizagem (Dissertação de mestrado). Universidade de Caxias do Sul, Caxias do Sul. 
Ferreira, F. A. F. (2018). Mapping the fi eld of arts-based management: bibliographic coupling and co-citation analyses. Journal of Business Research, 85, 348-357.

http://dx.doi.org/10.1016/j.jbusres.2017.03.026.

Grácio, M. C. C. (2016). Acoplamento bibliográfico e análise de cocitação: revisão teóricoconceitual. Encontros Bibli: Revista Eletrônica de Biblioteconomia e Ciência da Informação, 21(47), 82-99. http://dx.doi.org/10.5007/1518-2924.2016v21n47p82.

Gramigna, M. R. (2007a). Jogos de empresa (2. ed.). São Paulo: Pearson Prentice Hall.

Gramigna, M. R. (2007b). Jogos de empresas e técnicas vivenciais (2. ed.). São Paulo: Pearson Prentice Hall.

Kroehnert, G. (2001). Jogos para treinamento (D. Aparício, Trans.). São Paulo: Manole.

Martinelli, D. P. (1988). A utilização dos jogos de empresas no ensino de administração. Revista ADM, 23(3), 24-37.

Mattar, J. (2010). Games em educação: como os nativos digitais aprendem. São Paulo: Pearson Prentice Hall.

Odenweller, C. M., Hsu, C. T., \& Dicarlo, S. E. (1998). Educational card games for understanding gastrointestinal physiology. The American Journal of Physiology, 20(1), 78-84. https://doi.org/10.1152/advances.1998.275.6.S78.

Pantaleão, L. H., Oliveira, R. M., \& Antunes, J. A. V., Jr. (2003). Utilização de um jogo de produção como ferramenta de aprendizagem de conceitos de Engenharia de Produção: o jogo do barco. In Anais do XXIII ENEGEP. Rio de Janeiro: ABEPRO.

Prensky, M. (2001). Digital game-based learning. New York: McGraw-Hill.

Ramirez, D., \& Squire, K. (2015). Gamification and learning. In S. P. Walz \& S. Deterding (Eds.), Gameful World: approaches, issues, aplications. Cambridge: MIT Press.

Santos, R. V. (2003). "Jogos de Empresas" aplicados ao processo de ensino aprendizagem de contabilidade. Revista Contabilidade \& Finanças, (31), 78-95.

Sauaia, A. C. A. (1995). Satisfação e aprendizagem em jogos de empresas: contribuições para a educação gerencial. São Paulo: Universidade de São Paulo.

Schafranski, L. E., \& Tubino, D. F. (2013). Simulação empresarial em gestão de produção. São Paulo: Atlas.

Silva, T. C., \& Amaral, C. L. C. (2011). Jogos e avaliação no processo ensino-aprendizagem: uma relação possível. REnCiMa, 2(1), 1-8. http://dx.doi.org/10.26843/rencima.v2i1.47.

Teixeira, R. C. F., \& Teixeira, I. S. (1998). Jogos de empresa um instrumento para o desenvolvimento gerencial. In Anais do XVIII ENEGEP (pp. 1-9). Rio de Janeiro: ABEPRO.

Trybus, J. (2009). Game-based learning: what it is, why it works, and where it's going. Retrieved in 2018, July 15, from http://www.simcoachgames.com/pdfs/WP-Trybus-Game-basedlearning.pdf

van Eck, N. J., \& Waltman, L. (2010). Software survey: VOSviewer, a computer program for bibliometric mapping. Scientometrics, 84(2), 523-538. http://dx.doi.org/10.1007/s11192-0090146-3. PMid:20585380.

van Eck, N. J., \& Waltman, L. (2017). Citation-based clustering of publications using CitNetExplorer and VOSviewer. Scientometrics, 111(2), 1053-1070. http://dx.doi.org/10.1007/s11192-017-2300-7. PMid:28490825.

Walz, S. P., \& Deterding, S. (Eds.). (2015). Gameful world: approaches, issues, applications. Cambridge: MIT Press. http://dx.doi.org/10.7551/mitpress/9788.001.0001.

Zupic, I., \& Čater, T. (2015). Bibliometric methods in management and organization. Organizational Research Methods, 18(3), 429-472. http://dx.doi.org/10.1177/1094428114562629. 